\title{
Iberian Overseas Expansion and European Trade Networks
}

In 1526, Charles V married Isabel of Portugal. In doing so he put in place the groundwork for the dynastic union with the last of the peninsular kingdom to have escaped the gravitational pull of the Habsburgs. At this point the Portuguese and Castilians were involved in collaborations, entanglements, and conflicts stretching from Asia to America, thus forging the foundations of a global system. Clearly, this system was precocious and sophisticated, simultaneously partitioned and interconnected (Subrahmanyam 2007; Bethencourt 2013). In spite of that sophistication, paradoxically, this imperial experience has provided the basis of a very negative interpretation of the history of the Iberian Peninsula. According to this interpretation, oceanic expansion converted Iberia a 'semi-periphery' within Europe, serving simply as a conduit for the export of raw materials, some of them obtained from their colonies, to the north of Europe, while industrial products manufactured in the 'centre' of this emergent world economy - in other words, in the north of the old continentwould flow in the opposite direction (Frank 1978; Wallerstein 1979).

\section{Sailing the Atlantic, Conquering America}

In 1492, the Spaniards made the leap into America. In 1497-1499 Vasco da Gama rounded the Cape of Good Hope and reached India. In 1520, Ferdinand Magellan sailed through the straight that would take his name,

B. Yun-Casalilla, Iberian World Empires and the Globalization of Europe 1415-1668, Palgrave Studies in Comparative Global History, https://doi.org/10.1007/978-981-13-0833-8_2 
and following his death Juan Sebastian Elcano returned to Spain as the first man to circumnavigate the world (1522). What was behind these names? Columbus was not of Castilian origin: he was Genoese and had acquired much of his knowledge in Portugal. Magellan, sailing on behalf of Charles V, was in fact a subject of the King of Portugal. If these details are apparently superficial, they should not blind us to the fact that from the very beginning of the primitive globalization, these initiatives were the result of cross-border entanglements and patterns of knowledge that were profoundly interrelated.

\section{Challenges and Tools}

When in 1519 Cortés landed in Mexico and began to take an interest in this 'second America', the gold reserves of the Caribbean were nearing exhaustion. The following years would see the conquest of both Mexico and Peru, where the Spanish found extensive political formations that were overcome so rapidly that one historian has observed that by the 1540s the New World 'was already conquered, in so far as Spain would conquer it' (Davis 1976, p. 52). But the extraordinary speed of the conquest should not lead us to forget the problems posed by it and by the control of these vast new domains.

America was, perhaps, seen by many as a promise. But it presented, to all and sundry, a challenge of dimensions that were difficult to imagine. This most definitely was the case for Castile, which faced not only the challenge of conquest but also the struggle to control and to exploit American peoples and wealth. ${ }^{1}$ America was a distant continent of vast, unimagined proportions, with ecological and geographical conditions ranging from deserts to rainforests. Europe's best sailors and cartographers took some time to represent a geographical reality that was, in the first instance, unfathomable. After the exhaustion of Caribbean gold reserves, Spain faced the problem that some of the riches that the Spaniards were seeking, such as Inca gold and silver, were found in particularly remote and inhospitable areas. This having been said, the richest areas would turn out to be

${ }^{1}$ A definitive study of the global impact of what could be called the 'globalisation of America' has yet to be written. This is not the place to undertake any such effort. Here we can only underline a number of the most important aspects of it for the purposes of this book. 
just to the north (the Aztec confederation) and to the south (the Inca Empire) of the Caribbean Sea, which quickly emerged as the cornerstone of interactions with the Iberian Peninsula.

Geography and environmental systems imposed serious constraints upon communication. Dependence upon the winds and the ocean currents led to long stationary periods during voyages and caused lengthy delays in travel across the oceans. Even after a communication system was organized, Chaunu has calculated that a round trip between Andalusia and Mexico took some eighteen and a half months, of which only five were actually spent in sailing. In the first place, this posed a political problem due to the delays affecting orders and communication between the metropolis and the colonies (Chap. 7). But it also constituted a serious financial drawback, resulting in a long period in which capital would be immobilized, with the subsequent high costs for traders. In addition, given the unpredictability of the weather, the inevitable and long delays, and the need for security, vessels were loaded with as many foodstuffs, weapons, and ammunitions as possible. While these measures represented sensible planning, they proportionally decreased the voyages' overall profitability. The increase in the vessels' dimensions, moreover, would bring new problems when the convoys came to pass over the sandbars at the mouth of the Guadalquivir River. In effect, they were often forced to wait for high tides near the Cape of San Vicente, the area of maximum danger for corsair attack. These were some of the reasons why trade was skewered towards goods that were very expensive relative to their weight, such as gold, silver, or slaves, and made use of others, such as hides and leathers, as a kind of very low-cost ballast freight, whose function was to balance outgoing loads (Chaunu 1977, p. 45).

There were also problems of a more strictly social—or human—origin. The conquest and organization of territory were relatively rapid in the areas where extant political structures were more advanced. In this regard it was important that the Aztec confederation and Inca Empire were minimally centralized and that, with the fall of their centres of power, Spaniards took control of extensive and efficient networks apt for the ruling of their territories. But the limitations on the control of territory were very considerable across much of the continent, where there remained many tribal societies in inhospitable areas that were very difficult to access (and often, also, these were of relatively little interest to the conquistadores). In any case, the problem lay not only in conquering distant regions but also in maintaining them. This is to say that the question was how to mobilize 
resources — human and technical—for conquest or how to incentivize this process without relinquishing control of these territories. But it also concerned how to maintain a small group of colonists in situ among a population that dwarfed them.

Yet even where conquest had been achieved, it was not always easy or possible to exploit the available resources. As the Portuguese had exploited well-established trade routes in the Indian Ocean, the Castilians took advantage of extant tributary networks. However it was difficult to force the population to toil for its conquerors. Moreover, no labour market existed to provide a workforce. Of course, Indian institutions existed for the use of forced labour in return for the exchange of gifts and compensations (Menegus 1991). But to get these to function on the necessary scale was a major problem. The most sought-after resources in the initial phase-gold and silver-were not easy to obtain and posed technological problems. During the first phase, in fact, the progress in mining was based upon a 'mixing of European techniques and those inherited from the old settlers'. But towards 1550, and despite the abundance of mineral deposits, 'diminishing returns' started to make themselves felt (Sánchez 1989, vol. I, pp. 311-2) that could only be overcome by a technological leap forward. For silver mining this meant addressing the basic technical problem of mineral amalgamation. This had to be done with mercury, a product then available only in Europe and China, which obviously increased the final cost of production (Sánchez 1989, vol. I, p. 324). And these are only a few of the examples of the difficulties faced by these crucial sectors during the conquest.

The situation can be better understood if we also consider the shock that the discovery of this New World was provoking among Europeans. As is well known, the mere existence of America and its inhabitants compelled Europeans to reject the authority of traditional ideas and start to envisage reality from a platform provided by empirical observation (Elliott 1972), as would the later discoveries of Kepler and Galileo. Over the course of the sixteenth century, empirical observations would progress in auxiliary sciences such as botany and through the collection of words or the study of languages such as Quechua.

The encounter between different civilizations also affected the concept of the Indian and led to discussions about his status as a human being. On the one hand, for the first Dominicans, the Amerindian embodied an unblemished soul, the clean slate (tabula rasa) described by Aristotle upon which the values of the most pristine forms of Christianity might be 
inculcated. On the other hand, for the conquistadores the indigenous communities represented mostly an untapped reservoir of expendable labour. In this sense, the challenge lay not in the existence of a new reality that needed to be understood but rather that it produced an array of interpretations that were seized upon in competing fields of interest. In juridical circles controversies of this sort were very prominent in what Tomás y Valiente (1992) called the 'critical stage' between 1511, when the first voices were raised against the exploitation and even the enslavement of the Indian, and 1566, with the death of Bartolomé de las Casas, who had been the most resourceful and committed defender of the rights of the indigenous population.

These challenges notwithstanding, until very recently scholars have held that Castilian society was poorly equipped for this endeavour. In this light, the negative effects of the conquest were easily explained. ${ }^{2}$ But Castile was in fact one of the areas of Europe best prepared for a challenge of these proportions. It boasted human capital and institutions well-suited to such a gigantic undertaking. It stood in the vanguard of navigational advances and had seen the emergence of advanced forms of military organization that some historians have considered to be a key element in Europe's unique historical trajectory (Hale 1985, Chap. 2). Financial techniques and institutions were already highly developed and would shortly be supplemented by the emergence or adoption of systems such as the Italian commenda and compagnia, crucial to any drive to accrue the capital necessary for the colonial adventure (Macalister 1984, p. 98). Castile boasted a multitude of foreign merchants, with Italians and, specifically, Genoese, keen to become involved in Seville.

In addition, the Iberian Peninsula harboured local institutions that for centuries had overseen campaigns of military expansion and colonization that were almost unique in Europe (with the exception of expansion eastward from Germany). The control of territory in the New World came to be based upon municipalities very similar to those that had been formed in the Iberian Peninsula during the Reconquista, with the establishment of the town council (the cabildo), the local by-laws (ordenanzas), the municipal district (alfoz), and the extensive communal estate over which the

${ }^{2}$ John Elliott (2006), however, has recently called our attention on the pioneering character of this Castilian enterprise and underlined that the English expansion into the New World involved a high degree of imitation of it. See also Cañizares-Esguerra (2006). 
town would exercise its jealously guarded jurisdiction (Weckmann 1993). As civic ceremonies and rituals emphasized, all of these bodies or institutions served the king and his justice (Macalister 1984). In contrast to the later English programme, Iberian colonization was very much directed from above (Elliott 2006, pp. 117-9). After the first problems with Columbus alerted the Crown to the need for caution in order to avoid any relative loss of power, Castile would resort to pre-existing formulas, such as capitulationes, a type of accord between the king and a conqueror that maintained royal sovereignty in exchange for the governmental and economic concessions in recently discovered lands (Aram 2008; Carrasco and Céspedes 1985, p. 291).

As we have seen, the monarchy maintained a fiscal apparatus rivalled only by France. The creation of the Council of the Indies (1524) gave it a central body capable of directing and controlling-or attempting to control-the New World's political organization. Castile had also overseen the development of judicial institutions that would become basic to the regulation of social relations in the New World. The Castilian Chancillerias served as a model for the Audiencias responsible for the administration of justice in America, while the Aragonese viceroyalties provided a template for a political figure-the viceroy-who might be seen as a kind of 'alter ego' of the king in the overseas dominions. Both institutions increased the government's ability to regulate social life and territory and thus its coercive power. They operated thanks to a bureaucracy of lawyers trained in some of the Old World's best universities (themselves representative of one of the earliest and most impressive manifestations of the 'educational revolution' sweeping over the continent) and whose judgements and interpretations would lead to the emergence of the so-called Derecho Indiano (Indian Law), a pioneering effort to adjust Castilian legal traditions to the specific circumstances of the Indies (Tomás y Valiente 1992, pp. 325-45). This group of royal officials and interpreters of the laws of the kingdom together with the alcaldes mayores and the corregidores, the main authorities at the municipal level, exercised judicial and governing powers. At an early point, the Crown obtained from the Pope the right to nominate bishops (derecho de presentacion) in the Indies. In fact, Rome had previously allowed the Crown to claim all tithes paid by its American subjects. In addition to providing the Crown significant revenues, these measures gave it a valuable source of patronage and offered it a high degree of control over what was to be one of the main pillars of the colonization-religion and religiosity. 
At the same time, the problems in establishing a labour market were overcome through the repartimientos de indios, that is, the temporary distribution of Indians as a workforce for the colonizers, and the encomienda, which saw a certain number of Indians given to the colonists on a permanent basis, with the natives being obliged to pay tribute or work in exchange for protection and being taught the Christian religion. Moreover, ownership formulas that were common on the peninsula, such as the mayorazgo, entailed ecclesiastical property and others, gradually extended to the New World, where they would have an enormous impact on institutional frameworks and property rights (Coatsworth 2008).

The basic infrastructure for the control and processing of information in this vast empire and in the European territories took the form of the creation of central archives such as that of Simancas, maps and geographical accounts (Relaciones geográficas) or descriptions of territories, and memoriales or reports. This information gathering occurred on a scale never before seen (Parker 2001). In addition to these surveys describing the new continent, visitas, or traditional visits involving the dispatch of officials to oversee the control of the administration, were undertaken. Juicios de residencia were also commonly used to evaluate the performance of officials at the moment of their replacement. All of these measures constituted a governmental attempt to achieve self-sufficiency in obtaining one of the most expensive resources of the time, information (Brendecke 2012). The 1560s and 1570s witnessed a genuine offensive on this front, with law graduates (letrados) providing coherence to the American legal system. Or, at least, this was the intention (Rivero 2011). From 1569 to 1571, Juan de Ovando was charged with reforming the Council of the Indies, the organism overseeing and upholding the laws of the Indies, with the aim of giving it a more central role. Parallel to this reform, the government created notary offices (escribanias) to register contracts and thus contributed to the regulation of economic and social relationships, something which at least offered the possibility of reducing transaction costs or, more accurately given the starting point, of converting an unmeasurable degree of insecurity into a risk that could at least be assessed with some degree of precision.

Over the century the fiscal system slowly was implemented within the apparatus for the mobilization of American resources. The collection of taxes such as the alcabalas and levies on alum, snow, playing cards, salt, and other goods proceeded at rates similar to those on the peninsula. This system was based around a growing number of cajas, treasury districts, 
established in the more important cities (TePaske and Klein 1982). In addition, the system for the transfer of funds from one caja to another (the so-called situados) was advanced. This arrangement, in turn, would become vital for the defence of territories and, in contrast to what occurred in Europe, based its efficiency on the absence of political and jurisdictional barriers between the different regions (Marichal and Souto 1994; Marichal and von Grafenstein 2012). The system stretched as far as Manila (Alonso 2012).

A sophisticated convoy system was also organized, combining warships and commercial freighters, aiming to guarantee the Crown's commercial monopoly and to resist attacks of corsairs from countries such as England and, later, Holland. Based upon a delicate balance between geography, climate, technology, and human and nautical resources, this system was organized from the House of Trade (Casa de la Contratación) in Seville (1503) (Parry 1990, pp. 53-6; García-Baquero 1986, pp. 23-30). The convoys would become the basis of the Carrera de Indias, a description of which gives a clear idea of the high degree of sophistication often present in the colonial system (Map 2.1). ${ }^{3}$

\footnotetext{
${ }^{3}$ The system, as it began to be regulated during the 1560s, was as follows: each year Sanlúcar de Barrameda witnessed the departure of two fleets, one in May and the other in August; both sailed with armed protection and were loaded with wine, oil, textiles, luxuries, swords, books, grains, and other goods sought by a colonial elite with high purchasing power. Their voyages lasted between five and six weeks. The May fleet headed to Vera Cruz (Mexico) and the August convoy towards Nombre de Dios and, after 1597, Portobello (Panama), where they unloaded their cargoes and retired to overwinter in Cartagena de Indias. The outward journey was relatively easy, all things considered; the real problems lay in coordinating the return to Spain, which depended upon uniting in Havana at the beginning of summer, before the arrival of the hurricane season. The fleet from New Spain, loaded with silver, cochineal, and other products, could do this quite easily, even though it had to set sail from Vera Cruz in February so as to take advantage of the trade winds. Its voyage lasted three to four weeks. Problems were greater for the galleons that had to collect the silver coming from the mines of Potosí to Panama; here precision and timing were crucial, and the whole operation depended on the co-ordination of many linked factors. Ideally, the linking up would be achieved in March, so that it would be back in Havana before the hurricanes. But for this to occur, it was necessary that it should rain early in Bolivia - an uncommon occurrence-so that the mills could prepare the ore and melt the silver into ingots. When this process was accomplished, a long chain of llamas carried it down from Potosí to the port of Arica (15 days), where it was sent to Callao in Lima and then loaded and shipped, aboard special vessels, to Panama (20 days). From there it was transported on the backs of mules across the isthmus to Nombre de Dios or Portobello (at least four days travelling), where the fleet awaited it.

If this delicate mechanism of synchronicity and co-ordination worked, the fleets could reach the sandbar that accumulates at the mouth of the Guadalquivir in August (the best
} 


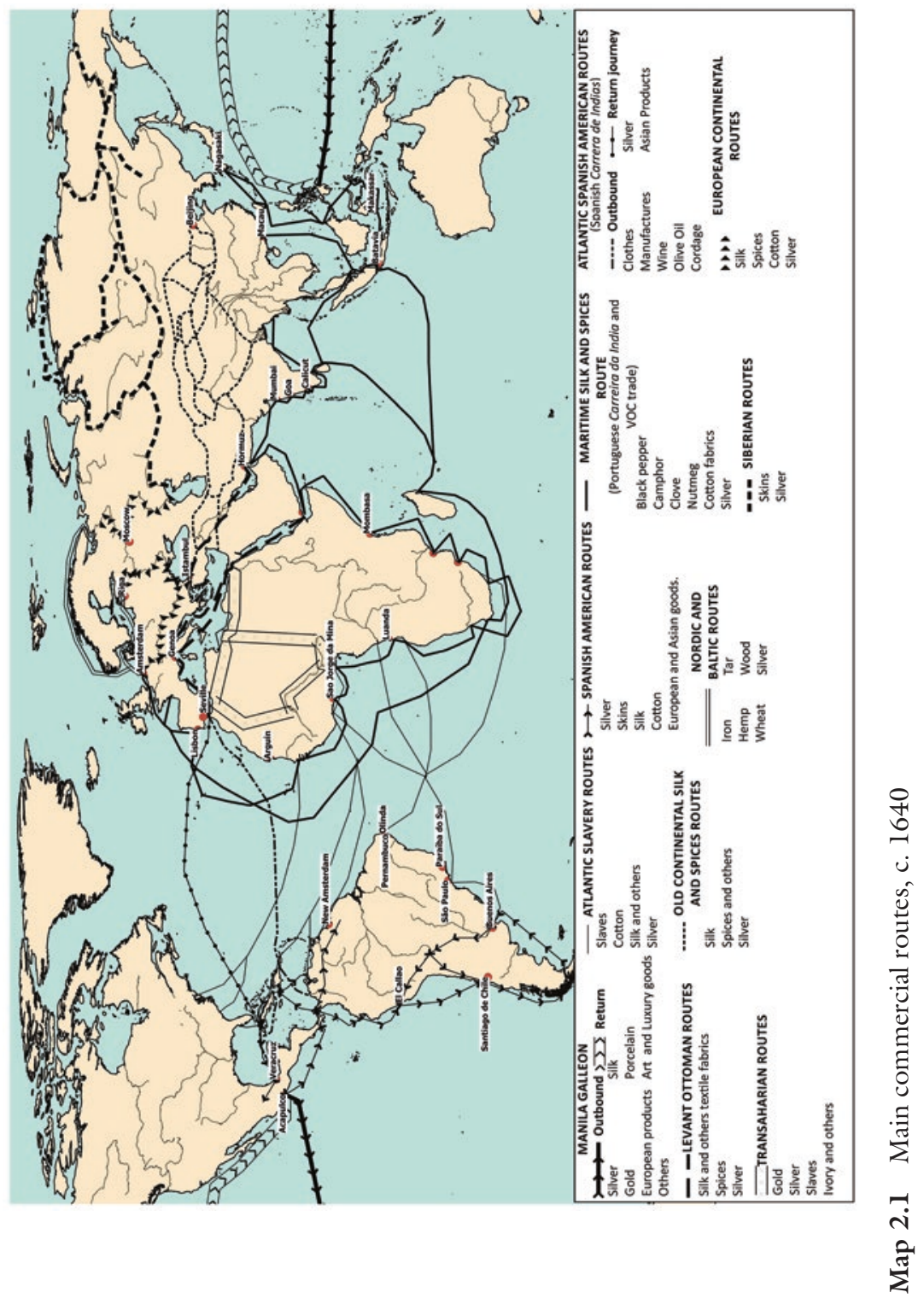


The Carrera de Indias belies the old myth of Spain being a country with little organization or technological capacity; it also demonstrates the development of methods of observation and organization as a means of understanding nature, oceanic currents, and winds. This methodology was already evident in the process of oceanic expansion. But it developed even further thanks to the voyages and the foundation, in 1508, of the School of Pilots of Seville (Schäfer 2003). In this same period, medical doctors such as Monardes and theorists such as Arias Montano and Acosta would make a considerable contribution to the use of empirical observation as a means of understanding the New World (Aram and Yun 2014). New technologies in the mining sector would also be crucial. The exhaustion of ground-level deposits and the crisis in silver production based on the traditional smelting furnace were resolved by the development of a method for its amalgamation with mercury, which reduced costs and lessened the technological dependency on the peninsula, thanks to the exploitation of the mines of Huancavelica (Sánchez 1989, pp. 310-32). The Spanish empire was in reality a stage for scientific and technological development that barely resembled the pessimistic visions of it to which we have become accustomed (Barrera-Osorio 2006, pp. 6-12). This technical capacity quickly manifested itself in another series of advances that would have a marked effect upon the sixteenth century and ran from the use of animals such as mules to the introduction of sugar mills.

\section{Political Control, Bargaining, Resistance, and Environmental Failures}

Despite Iberian societies' extraordinary capacity to mobilize material, institutional, and human resources, the outcome would not be an American society that was tightly controlled from Castile. In the first place, the very means of financing the conquest led to forms of negotiation that would have an enormous impact upon the political economy of

time to cross it) and so enter into what was a very safe harbour. In fact the galleons often reached it between September and October and so were forced to wait for high tides or high river levels to overcome the bar; alternatively goods could be unloaded onto barges. This task was carried out near the Cape of San Vicente, the area of greatest danger for attacks from corsairs or pirates; this problem would be more common as the size of ships increased over the course of the second half of the sixteenth century.

Elliott (1990, pp. 41-3), on the basis of the reconstruction of Báncora (1959). 
the colonies and the imperial system sensu lato (Chap. 7). Moreover, the conquest was a disaster and a failure in humanitarian, demographic, and ecological terms.

In distinction to modern empires of the nineteenth century, Iberia's sixteenth-century imperial enterprises were not paid for in economic currency dispatched from the metropolis or other colonies. Rather, they were financed through a multitude of accords made at the local level between the king and the conquerors and colonizers, including the religious orders. These negotiations had no jurisdictional framework as defined and formalized as in the composite monarchies of Europe, in which the cities, nobles, and Church exercised legal powers of coercion (Chap. 1). For reasons set out (above), the Crown took great care not to cede effective jurisdiction to private individuals. This has sometimes led to the impression that the government of America was based upon the unanswerable and absolute power of the king. Yet the very system of conquest, based on capitulaciones and general concessions of political rights and economic privileges by the Crown to the conquerors, created a form of do ut des and depended upon the exchange of privileges in the use of natural and political resources that from the very beginning nuanced the effective power of the king. What the conquistador-Columbus himself is the most evocative example-received was the recognition of his 'privileges' to use resources or to govern in return for his extending the dominions and resources of the king. The encomiendas and repartimientos of Indians also implied this type of transaction. Both were based on the Crown's ceding of tributary advantages or the use of a workforce in return for colonization. From this basis sprang the later problems faced by the monarchy in revising the conditions it had set down for the first conquistadores, as did the settlers' subsequent revolts and obstructionism, both of which were fully justified from their point of view. The empire was built on an exchange between the Crown, which saved the most precious of all resources - money-by conferring political and social capital, and the effective capacity for enforcement upon the colonists. This was done, however, on the grounds of the preservation of royal jurisdiction and the creation of formal institutions of government that were, in appearance, at least, dependent upon the king.

A process of this sort did not avoid permanent conflicts. An attempt to institute reforms in 1542 known as the Leyes Nuevas provoked settlers' rebellions. The policy on encomiendas, for instance, the suppression of vacant ones, triggered considerable resistance among their holders. In Peru things went as far as open conflict in 1544. It proved possible to 
avoid this outcome in New Spain thanks to the necessary adjustment being made in time, but in 1564 a new wave of discontent broke out and led the rebels to name the son of Cortés as their legitimate king.

The other step to the articulation of dominion, the relations between colonials and Amerindians, led to more than one flare-up and resulted in armed uprisings. As early as 1536, this difficult relationship led to the Peruvian rebellion of Manco Cápac, giving vent to forms of dissent that would last until 1572 and would lead to the foundation of the independent kingdom of Vilcabamba and the spread of millenarian beliefs that encouraged resistance. Attitudes were, clearly, changing. In this period, 'rebels' not only learnt to fight against horses by constructing pits or throwing balls at their legs but also, according to the account of Titu Cusi, son of Manco himself, reinforced their old religious beliefs by identifying the Christian deity as a false God consisting of nothing more than painted cloth and clearly bettered by the visible gods - the Sun and the Moonwho communicated with their people. The emergence, from 1564, of the religious movement of the Taqui Ongo was consistent with these developments and with the traditional cyclical conception of history. This programme assumed a messianic character and announced the resurrection of Pachacamac and a victorious revolution against the Spaniards. These beliefs would become so enduring and deep-rooted that they would resurface in the eighteenth century. The same could be said of the forms of frontier resistance, such as that of the araucanos (in today's Chile, and which lasted until the nineteenth century and displayed a remarkable degree of military adaptability), and uprisings in the humid zone of Mexico, among the Chichimeca, who would never in fact be conquered. Indeed, it has even been argued that 'the entire colonial history is marked by resistance and revolts' (Bennassar 1980, pp. 221-52).

In the midst of such unrest, the encomenderos certainly became progressively stronger and created the conditions for political bargaining with the Crown on a new basis. The demographic crisis, leaving huge unpopulated spaces, provided the encomenderos with a pretext to dominate peoples and to control their land. Some encomenderos proclaimed themselves owners of the possessions - principally the land - of greatly diminished or entirely absent communities. By the middle of century, 'much of the Mexican plateau had fallen into the hands of a few wealthy individuals' (Davis 1976, p. 57). In areas devoted to mining, which held such enormous interest for the Crown, the needs for labour led to similar processes and changes. With the demographic recession and technological innovations, mining became 
a high-cost activity that relatively few settlers could afford to enter. These developments were accompanied by a remarkable effort by the merchants of Lima and the ecclesiastical institutions to finance mining operations, making efforts that were decisive in providing liquid funds for a key sector of the colonial economy. Such developments cemented in place another important facet of the relationship between the monarchy and its subjects, the basis of which was a flexible application of the law and which allowed the Crown to claim its share-the 'royal fifth' - of production. This 'accord' would prove to be the basis of the great cycle of American silver flowing onto the peninsula between 1550 and 1600-1610. If it wanted to make the Indies a source of income, the Crown had to facilitate the work of these merchants and ecclesiastics. Its relationship with them, if usually marked by tensions, was always based upon reciprocal and mutual need.

The understanding between local authorities and the Crown was reflected in the decentralization of the Derecho Indiano, something which even permitted the survival of indigenous laws and customs. Common to all of these developments was recourse to the long-established Castilian tradition of 'obeying but not complying' with the law, a custom used by the municipal councils of many cities as a way to 'oppose the authoritarianism of the King and his officials' (Tomás y Valiente 1992, pp. 337-41).

This mixture of pressure, resistance, and asymmetric transaction was also clear in the process of the religious acculturation of the indigenous population-and, indeed, in the limits to this process. Anthropologists have shown that the efforts to change the culture and mental world of the Indians had certain limits, in large part because of the syncretic nature of many religious beliefs. As the case of the Maya makes clear, the outcome was often a hybrid type of religion that displayed on the one hand a capacity for resistance and, on the other, the negotiating structures that had to be adopted (Farris 1984, pp. 442-536). Religious syncretism entailed another way of compromising, one paid for in blood in many cases but not less important than the other accord with the king: this was the agreement that the local chiefs and indigenous lords should not only organize the collective tasks to pay the tribute but also its transfer, a part of which they duly retained for themselves (Menegus 1991). The relationship was also based upon the Church, whose expansion implied the development of another important actor in political and economic affairs as well as religious ones. The Franciscans, Dominicans, and Jesuits acted as mediators between colonists and Indians and were subject to the same exchange of forms of capital, including economic resources, with the monarchy. 
From the demographic and humanitarian point of view, this system and the contact between these two worlds resulted in a catastrophe without precedent in the history of humanity. A key starting point to understand sixteenth-century America is the way the combination of ecological forces and institutions led to what Las Casas called the 'destruction of the Indies', the demographic catastrophe following the conquest. Whatever the population figures of America in 1491, it is clear that the indigenous population was sizeably reduced in the following decades. Thus, for central Mexico-a region that has generated considerable controversy-Borah and Cook postulate a fall from 25 million inhabitants in 1519 to 1.38 in 1595. This is, perhaps, overly dramatic. But, even taking more recent attempts at revision by scholars such as Zambardino (from between 5 and 10 million to 2.2 and 3 million in 1568), it is impossible to deny that the Amerindian population fell between $50 \%$ and $70 \%$. This obviously entailed dramatic consequences for the economy of the area and workforce availability. Some calculations even suggest a fall of between 60 and 80 million inhabitants in 1500 to 10 million in 1600 , including European immigrants. ${ }^{4}$

As it is well known, this breakdown in American history has been the cornerstone of the so-called Black Legend, which portrays Spain as a cruel country destroying not only American resources but above all native American populations and cultures.

Over the last few decades, however, a rich vision of the ecological clash of these two worlds has emerged and has gone a long way towards explaining the 'means' of conquest-in other words, the environmental factors that facilitated this process. The 'ecological imperialism' analysed by Crosby was, no doubt, a key factor (Crosby 1988). Diseases such as smallpox ruined the lives of thousands of Indians (and strengthened their belief in the divinity of the Spaniards, whose resistance to the epidemic was far higher). Focusing upon illnesses, John Elliott has written that 'the most effective of all the allies for the imposition of European supremacy was not human, but rather biological' (2006, p. 112). Plants such as white clover, which quickly spread through Peru as fodder, displaced the Incas from fields that had been vital for their livelihood. The pig, an omnivore requiring high quantities of carbohydrates, competed with the Indians for highcalorie foods. Semi-wild cattle spread very quickly throughout Mexico and other regions. Together with proliferating numbers of horses, they helped

\footnotetext{
${ }^{4}$ See figures in Maddison (1995) or some different but equally meaningful estimates in Romano (2004, Chap. 1).
} 
destroy much of the foliage that was very delicately balanced in some zones. ${ }^{5}$ This vision somewhat shifts the accent from human action and cruelty to more impersonal factors and, no doubt, contributes to a less maniquean view of the 'destrucción de las Indias'.

Yet one needs to consider ecological imperialism not only as the encounter of flora, fauna, and microorganisms, as is usual, but also in relation to the role played by the institutions, cultural beliefs, and patterns of knowledge regulating the uses of resources and ecosystems. Today it is clear that the logic of how the encomienda functioned would be crucial. Amerindians were awarded to the encomenderos as a workforce or as tributaries for a temporary period designed to be cancelled at some point, when the Indians would revert to the Crown. Hence there emerged a tendency towards the quickest possible exploitation of the Amerindian population as an essential part of this drama. In the same way, the repartimientos of indigenous peoples and the use of mitas (personal labour services that the Indians had to perform in the mines) involved the massive displacement of individuals from their communities to the mining areas, thus exerting a dramatic effect upon the original social structures and demographic equilibrium. These institutions, moreover, did not act in a vacuum but, rather, in combination with environmental forces. The settlers' efforts to maximize profits-an objective inherent to their cultural beliefs and aspirations-came on top of intensive rhythm of work that these institutions demanded of the Amerindians and for which the physiology of the native population was entirely unprepared. In many areas the diet of the Amerindian population-and diet is a crucial component of all living beings in any ecological system-was based on carbohydrates drawn from the manioc plant, maize, potato, and other crops; physiologically, such natives were unprepared for the encomenderos' demands for continuous exertions in the fields and mines (Bennassar 1980). On the other hand, the destruction of the original ecological systems combined with forms of social and institutional organization unprepared to confront the ensuing environmental challenges. The introduction, for example, of European crops and technologies associated with the new institutional frameworks created by the Spaniards arrived but spread too late to avoid the demographic catastrophe. ${ }^{6}$

\footnotetext{
${ }^{5}$ Crosby (1988), McNeill (1977, pp. 176-207).

${ }^{6}$ The results of the work in progress of Bethany Aram and her research group, 'ArtEmpire', should clarify many of these questions, which are often absent from the relevant bibliography.
} 
The institutional component of this process, if often marginalized by historians, was highly significant. Legislative measures were clearly unable to stop or prevent the exploitation of the Amerindian population, nor was the medicine of the time capable of meeting the challenges posed by the 'microbial unification of the world', in Le Roy Ladurie's memorable expression (1973). Las Casas denounced this situation to Charles V at the very moment of the emission of the 'New Laws' (Leyes Nuevas, 1542), which sought to supress the encomiendas (and in fact did so in certain areas), and attempted to end the exploitation of the Indian. The logic of Las Casas' programme lay not only in human rights and religion, as has often been said. It was also based upon the peninsular experience of a continual stripping away and usurpation of the royal patrimony (Chaps. I and 4), it being somewhat of an obsession of the Crown to avert a similar process in the Americas. In fact, this was what was occurring from the very moment that subjects of the king-the Indians-died in harsh labour systems. But the remedy was worse than the illness. The new measures unleashed even more ferocious desires for exploitation of the workforce. Legislation camouflaged, but did not prevent, abuses in a distant world in which the capacity of enforcement of the royal courts-and, therefore, their ability to arrest abuses - was very limited (see below). The need for a labour force justified wars of conquest often based upon the idea of the existence of cannibalism (this was not always certain), which was seen as a symptom of barbarity. The notion of the barbarous served to justify not only war but also forced work systems such as the repartimiento, which were thought to offer the redemptive and civilizing power of work to the barbarian population (Córdoba 2013). As is well known, the New Laws were also the pretext for the trade in American slaves, something legal and consistent with the cultural beliefs of the period.

In this way and to an extent, the Black Legend emerges as a rhetorical excess that undervalue the context of events and with profound consequences on the image of Spain. Such is even more the case considering attempts to avert the catastrophe, at least on paper and in some of the Crown's acts. At the same time, a purely ecological vision, based solely on flora, fauna, microbes, and so on, overlooks the human and institutional components of the process, especially if the period's cultural beliefs, in which humanitarianism and human rights were much less developed than today but were already in the mind of people such as Las Casas, provided the foundations of this institutional framework. Between both extremes lies a third more complex, but also more realistic and less 
maniquean, possibility. The environmental problems, illnesses, interests, and abuses combined with certain political economies that neither acted nor were capable of acting to avoid a process of resource destruction that implied, even in the midterm, a disaster with characteristics new in the history of humanity.

\section{The Portuguese Empire and Asia: Bargaining, Diversity, and Limits}

At the conclusion of the reign of Manuel I of Portugal (1465-1521), the Portuguese were present on both the northern and eastern coasts of Africa, across the Indian Ocean, and even in the Chinese Sea. Moreover they had created a genuine Atlantic system that connected a range of archipelagos with the metropolis and with Africa and which was extended as far as Brazil.

Rounding the Cape of Good Hope early in 1498, Vasco Da Gama had sailed the coasts of East Africa with just two ships. Beyond this point the navigation became easier. Shortly afterwards he discovered that the coasts of the Indian Ocean were very navigable, although dangerous during the monsoon season. As with the great American empires-those of the Incas and Aztecsthe pre-existence of communication networks was vital to the giant strides subsequently made by the Europeans. Da Gama took more than a year to return to Lisbon with two great achievements (Parry 1990, Chap. 7).

The first of these was profit and, more important, he compiled information regarding the seas and coasts, language difficulties, societies, and religions. In Lisbon many intelligent Portuguese believed that, if conquered, India 'would weaken the forces of the kingdom to such an extent that it would be without those necessary for its conservation' ${ }^{7}$ But money and information was all that King Manuel-although partly mistakenrequired to embark upon a campaign of conquest.

As we have seen, the Portuguese empire was certainly not a work of Minerva-no empire, in fact, has ever been. A mixture of violence, piracy, fortresses, and factories, it included, when necessary, a form of diplomacy that went as far as the formal submission to local kings or the provocation of a massacre as a lesson to the others. Such methods served to overcome

\footnotetext{
7 'Debilitaría tanto as forças do reino que ficaria ele sem as necessárias para a sua conservaçao’. Quoted by Romero Magalhães (1997, vol. III, p. 521).
} 
the resistance of the Venetians, the Mamelukes of Egypt, and the Ottoman Turks, who looked unfavourably upon this new competitor-one who was, to make things worse, a Christian (Godinho 1982-1987). The strategy employed in these early phases demonstrated what would be the great strength and principal weakness of the Portuguese empire: the control of chain of key coastal positions, Goa (1510), Malacca (1511), and Ormuz (1515). Ormuz, an enclave ceded thanks to an agreement with the Safavid Persian dynasty that was confronting the Ottoman Empire, allowed for the control of the Persian Gulf and the chance to pressure the Turks in the Red Sea with the aim of cutting their involvement in Indian Ocean commerce. Goa opened up trade to India and constituted an excellent step towards the East. Malacca allowed Malaysia to be approached, thus making the Spice Islands (one of the principal foci of commerce in the area) reachable and allowing trade in the Chinese Sea, even touching Japan (Magalhães 1997, vol. III, p. 446). From the 1530s the expansion would be slowed and more focused on the consolidation of positions in this area. In 1529 the Portuguese had to recognize Castilian rights to the Moluccas (Indonesia). The Portuguese efforts against the Turk in the Red Sea ended in failure, and until 1555-1557 they were unable to establish themselves in Macao, where the Chinese reaction to the violence that they had used would stop them in their tracks (see the Portuguese routes in Map 2.1).

Enterprises of this sort capitalized Portugal's relatively few advantages, as a distant and small country with, consequently, very limited demographic resources. Nevertheless, to face the Muslim merchants connected to the Red Sea and Persian Gulf trade, the Portuguese called upon artillery-bearing ships of huge dimensions. The broadside (andanadas) tactic, consisting of bombarding enemy ships from the greatest possible distance, allowed the Europeans to sink or incapacitate their adversaries before direct hand-to-hand fighting-in which their adversaries' more numerous crews would have prevailed-could take place. This tactic also enabled the Europeans to sow panic in enemy ports and enclaves, sometimes with the aim of conquering them but, more often and simply, to make a show of strength. Obviously, the practice did not lead to the conquest of large territories, which would have been impossible from Portugal. The comparison with the Ottoman Empire, which had by this point conquered Mameluk Egypt, is revealing. The trade in spices in Antwerp afforded the Portuguese access to the timbers of the Baltic, while the Turk was making use of the woods of Anatolia and therefore facing extremely high transport costs (Headrick 2010, Chap. 2). 
The development of the sugar economy in Madeira, the Azores, Santo Tomé, and Cape Verde was followed by the emergence of Brazil. On Vasco da Gama's return from India, King Manuel immediately charged Pedro Álvares Cabral, un fidalgo da casa del rei, to sail for Brazil, a zone to the east of the line drawn by the Treaty of Tordesillas and, therefore, a land recognized as belonging to Portugal for exploration. This was followed by later expeditions along the eastern shores of South America and brought about contact with the Amerindians. Although trading concessions were made and some factories (feitorias) were created, at this point the country was too committed to the Indian Ocean in order to make great progress elsewhere (Disney 2009, vol. II, pp. 204-12). The halt in Portuguese expansion in Asia in the 1530s may be the reason for its subsequent attention to South America, where the French were gaining territory and seeking to obtain the wood (pao) of Brazil, a dye product very much sought by the businessmen of Nantes and Brittany and by the tapestry producers and tailors of Europe (Lockhart and Schwartz 1983, p. 181).

After 1550, however, Portuguese expansion in Asia slowed down largely due to confrontations with highly developed states and empires that were absorbing some of the West's military techniques (Darwin 2008, p. 74). Attacks upon Turkish positions in the Red Sea did not bring about decisive conquests, and the Portuguese dream of reaching Suez disappeared for a period of time. Indian Ocean piracy marked the Portuguese system. A realistic policy had led Portugal to abandon enterprises in North Africa, which came to be dominated by the rivalry between Charles V and Süleyman (Disney 2009, vol. II, pp. 125-9). By the mid-century, the differences between the Portuguese empire in Africa and Asia and the Spanish in America (and, indeed, the Portuguese dominions in Brazil) were already very clear: the Portuguese had encountered very solid political formations, with highly developed military technology (at least in comparison with the Aztec and Inca empires) and highly evolved internal social and economic systems and ecosystems adapted to European illnesses after centuries of contact. Together with the scarce population of Portugal, these circumstances explain the empire's highly limited capacity for penetration and domination. All of these factors would be decisive for the history of the empire.

As was the case for Castile in America, the system for the acquisition and control of territory had been based upon ceding political capital to private agents who would conquer and exploit the lands on behalf of the monarch in Lisbon. That is to say that feitorias and capitanias donatarias 
were created (above all this was the case in Brazil, which was divided into 12 such districts) each with the prerogative to penetrate into the hinterland (Lockhart and Schwartz 1983, Chap. 6). These districts were very similar to the metropolitan senhorios, and the government ceded the right to govern them in return for the conquest (Weckmann 1993). Another option was to employ a system of contrato in which private individuals received privileges to make use of the land. These were negotiated relations (Hespanha and Santos 1998, vol. 5, pp. 351-66) characterized by their very low cost to the royal exchequer, although, of course, they had a high opportunity cost for it in terms of its capacity for political control. In the case of Brazil use was also made of the foundation of cities (usually coastal ones), the outcome being that the population density of the hinterland would be noticeably lower than in Spanish America. These arrangements were conditioned not only by the difficulties in penetrating the hinterland but also by their character as enclaves within export-orientated economies that acquired slave labour from abroad and in return sent practically all of their produce overseas. As a result, royal influence in the cities of the Portuguese colonial world would be less marked and slower to establish itself than was the case in the Castilian colonies (Lockhart and Schwartz 1983, Chap. 6).

This having been said, it was obvious that the proper exploitation of this extensive network of contacts depended upon certain regulatory efforts and government from above. As in Spanish America, institutions with a strong centralizing tendency were established above the rudimentary ones on the ground. In fact, the Portuguese oriental empire was divided into two differentiated zones (Boyajian 1993) with interdependent but individualized institutions. The Casa da Índia, founded in 1503 and later imitated in Castile, was charged with regulating maritime space and overseas commerce and oversaw the royal monopoly in trade between Lisbon and Goa. Moreover, in theory the Portuguese system had a clearer monopoly than the Castilian one: while in Seville the Crown only regulated the trade between private individuals and attempted to respect the privileges of each city as a commercial licence holder, in Lisbon the king himself reserved the right to trade in determined products. The second institution was the powerful Estado da Índia, whose governor or viceroy was appointed by the monarch, resided in Goa, and was charged with the costs of protection, diplomacy, and enforcement in the Asian colonies. The Estado da India was charged with controlling and regulating Asian trade, a very important part of which was in private hands (Boyajian 1993, 
Introduction). Following the annexation of Portugal by the Habsburgs, Philip II (Philip I in Portugal) introduced centralizing projects in the Estado da India, with the creation of the Conselho da Fazenda (Miranda 2010 ) being of particular importance. In Brazil the office of the captaincy royal was created, with similar functions and its headquarters in Todos os Santos (Bahia), whence it governed Portuguese America. As in Spanish America, those captaincies that had been ceded in the phase of conquest were repurchased or redeemed to restore their government to the Crown (da Cunha and Monteiro 2005, p. 202). The Inquisition was used by the king to his own benefit and with an eye on the defence of his overarching or 'superior' authority (Bethencourt 2009). Equally the King of Portugal obtained from the Pope the right of patronage, known here as the 'presentation' of bishops, which conferred a notable power not only on political affairs but also, indirectly, on religious ones. And the King of Portugal also obtained the privilege to control the Misericordias in the empire and beyond it (Marcocci 2012, pp. 107-8).

Such methods are sometimes seen as a form of unconstrained absolutism that would shape the Portuguese empire: in reality, they were no such thing, and the system did not lead to the imposition of total or allencompassing monarchical power and, as a result, to institutional unification. In the Indies and in Africa, the distances and frontier character of many territories obliged the Crown to bargain with local actors of Portuguese origin and to negotiate with them over the administration of coercion, taking as a starting point the very heterogeneity of these territories and, consequently, the mixed nature of the resulting administration (Hespanha and Santos 1998, pp. 351-8). The very administrative reform programme itself, and the creation of the Conselho da Fazenda, was unable to overcome the enormous differences between tax-collecting centres and so led to negotiations between Goa and the local administrators. As a result, they retained a high degree of autonomy that led to 'systematic' corruption being accepted (Miranda 2010). The outcome was a negotiated process in which powers were ceded, thus implying a certain degree of autonomy. The African coasts, for example, were often in the hands of lançados, bandeirantes, and slavers, mixed with local populations, who exercised considerable autonomy (Disney 2009, vol. II, pp. 49-54). This was also the outcome in the capitanias donatarias, whose officers enjoyed considerable room for manoeuvre. The cities founded in Brazil fell into the hands of groups that enjoyed a notable degree of freedom of action and who received their privileges in return for their governmental and tax- 
collecting functions (Fragoso 2001, p. 47). In distant frontier territories, such as Brazil, the slavers operated with a high degree of autonomy and a de facto scope for negotiation that even allowed them to compete with the coastal cities in their power relations with the Crown (Lockhart and Schwartz 1983, Chap. 6). Overall the system, being based on the concession of institutional advantages in return for services or the mobilization of material resources, tended towards the creation of privileges that limited the right of the newcomers in regard to the previous negotiations with the Crown (Fragoso 2001, pp. 44-5). The viceroys and governors themselves, supposedly conduits for the transmission of the king's power, exercised a high degree of freedom of manoeuvre. The same can be said of bishops and clergy and, especially in this period, of the Jesuits who often pursued their own interests rather than defend the authority of Madrid or Lisbon (Valladares 2001, passim). And this tendency was even clearer in cities such as Macao, where the Portuguese authorities shared and negotiated the decision-making process with the Chinese (Hespanha 2001, p. 171).

This flexible form of articulating the power of the king and his vassals in the colonies was completed with pliable formulas of negotiation between the Portuguese settlers and the original populations. Here one of the keys was the creation of informal and complex relations, which included good doses of both initial violence and later matrimonial alliances and mestizaje (Subrahmanyam 2005). This fact is evident in Asia, where one of the crucial reasons for the survival of the imperial system lay in the capacity of merchants to mix and communicate with local societies. The fact that the very term casados (married) was used to describe the permanent residents of the Portuguese enclaves gives us an idea of the importance of these arrangements (Disney 2009, vol. II, pp. 147-9; de Sousa 2010). In Brazil the success of the capitanias, many of which had disappeared within a few decades of their creation, depended upon the establishment of informal networks that generated solid pacts with the local societies (Lockhart and Schwartz 1983, pp. 184-90). And this not only afforded an enormous scope for mediation to those who formed these pacts: it also increased their capacity to establish accords with Lisbon.

To the extent that these negotiations were extended and became used in different contexts, the result was what L. F. Thomaz (1994) called the different status of the territories composing the Estado da Índia and A. M. Hespanha has called 'a multiple colonial state' (2001, p. 170) and the emergence of a society where diversity and transactions between diverse social and religious identities marked the political economy. 
Apart from reasons rooted in the need to govern at long distance and over a society in which political negotiations largely depended upon privileges conceded by the king, this combination of negotiation and autonomy is due to the rise in the imperial sphere of informal global networks that generated a high degree of self-sufficiency. We will return to this point in Chap. 7. For the moment it is to be noted that the pattered applied to the case of the Jesuits, who by 1600 had created a global network and even were one of the solutions set upon by the Crown for the maintenance of Portuguese control in areas such as Brazil, China, and Japan. And this was also the case for merchant networks that, like the ones created by Jewish businessmen around their common identity and which gave them a presence in the colonies, took the form of well-forged grids that served to circulate news, information, capital (sometimes as dowries), and merchandise. These emerged at a very early moment and henceforth grew only in strength (Studnicki-Gizbert 2007).

\section{Overseas Trade and European Economies, 1492-1580}

\section{Silver and the Price Revolution}

The establishment of the Spanish and Portuguese empires meant an enormous step forward for the process of globalization. But what were the consequences of this first phase of globalization for Europe?

The question of the impact of the American economy on the old continent entails consideration of the arrival of precious metals and the so-called price revolution, the inflationary process that existed across Europe during the sixteenth century. Studies have demonstrated the existence of two clear cycles, the first lasting until the middle of the sixteenth century and marked by the shipments of gold and a slow increase in silver imports. The second, running from 1560 onwards, saw significant amounts of precious metals and, above all, an explosion in the amount of silver entering Seville. ${ }^{8}$ According to Barret, between 1492 and 1600, about 17,000 tons of silver and 280 tons of gold were produced in America, constituting, respectively, $74 \%$ and $39 \%$ of the world's total output between these dates (Barret 1990, p. 225). The impact, truly global, was particularly marked in Iberia.

${ }^{8}$ See above all Hamilton (1975), Attman (1986), Barret (1990), or TePaske (1998), Feliu (1991) and Reis (2016). 
Contemporary thinkers such as Azpilcueta and Bodin explained that a greater amount of monetized silver necessarily made prices rise, and Hamilton's studies as well as a long list of works on all Europe, and more in particular on the different Iberian territories from Portugal to Castile, Valencia or Catalonia have pointed in the same direction. ${ }^{9}$ Other historians have emphasized the importance, at least in Spain, of population growth as a key to inflation, underlining that prices grew faster in relative terms during the first half of the century and pointing out that in this timeframe the arrival of metals was proportionally lower, while population growth was pronounced. ${ }^{10}$ This argument was challenged by Harry Miskimin on the basis that the growth of American remittances must also be understood in terms of their relative increase, which was higher in the first half of the century with regard to the existing stock of money than in the second half of the century. ${ }^{11}$ Evidence for and against each one of these arguments has been presented in academic debates. ${ }^{12}$

Despite the huge interest of this debate from the perspective of economic theory, the most interesting element for many historians is not the question of whether or not the quantitative theory of money summed up in the Fisher equation is correct. As Miskimin himself has noted, this equation represents a tautology, and, consequently, it is 'fruitless to wonder whether or not it is the "truth" behind the European economy of the sixteenth century' (Miskimin 1989, vol. XIII, p. 181). The important thing is not so much to determine if inflation was the result of American treasure as to study how the increase in monetary circulation connected to other factors and developments.

A long time ago, authors such as Y. S. Brenner drew attention to the fact that, even while retaining the quantitativist paradigm by themselves,

\footnotetext{
${ }^{9}$ As is well known, the proponents of this theory have begun from the application of the equation of Fisher, which in its simplest form is usually set as MV = PT, where M is the monetary mass, $\mathrm{V}$ is the velocity of monetary circulation, $\mathrm{P}$ is prices, and $\mathrm{T}$ is transactions. The increase in the availability of metal would have been the basis for an increase in the monetary mass that would explain inflation. It would reach very low levels-around $2 \%$ annually-in comparison with today's rates, which proved, nevertheless, significant rate for the time (Hamilton 1975).

${ }^{10}$ Braudel and Spooner (1967), Nadal (1959), Vilar (1969, pp. 107-9).

${ }^{11}$ Harry Miskimin (1981). As (at least) a working hypothesis, Miskimin's argument can also be applied to the so-called pre-revolution of prices generated by the growing production of gold and silver in Central Europe.

${ }^{12}$ See a more developed version of these ideas in Yun (2004, pp. 128-38).
} 
population growth and economic development in the sixteenth century could cause an escalation in monetary velocity and thus induce an increase in prices. This view has been subsequently developed through the consideration of urban growth, in principle an indicator of the existence of an increase in the technical division of labour. According to Goldstone (1991), the sixteenth century witnessed a growing specialization of labour, suggesting a higher degree of intensity in the exchange of goods and services and, therefore, an increasing monetary velocity which could have encouraged inflation.

To clarify the real situation requires, however, a series of preliminary remarks. It is quite possible that the importance of the currency and, in particular, of gold and silver coin is sometimes exaggerated. Copper coins were still often instrumental in small trade. In addition, the economy of sixteenth century moved, in many periods and in many regions, through transactions in which the intervention of cash was non-existent. ${ }^{13}$ Moreover, the fact that at the highpoint of the century American treasures barely amounted to $7.5 \%$ of the gross domestic product of Castile-that is to say, possibly less than $0.5 \%$ of European total GDP-underlines that, in macroeconomic terms, its importance was lower than some have imagined (Yun 1998). However, the recognition of the marginal character of monetary circulation in some areas of Europe and in some segments of the economy does not imply that there was not a correlation between the variables set out above.

Although it can only be a suggestion, a comparison between New Castile, in the centre of the peninsula, and other areas of Europe is very indicative of the way in which these factors were intertwined. A comparative analysis shows how four variables, monetary circulation (measured both by the increase in the amount of silver in circulation and by currency devaluations), commercial and industrial development, and population growth, may very well explain the evolution of prices. In any of these different areas, they increased more when any one of these variables was combined with the others to provoke a rise in prices (Yun 2004, pp. 133-6). And, although this data may require a more robust quantitative exercise, everything suggests that in reality it was the different intensity with which

\footnotetext{
${ }^{13}$ Frequently, remuneration for rural and urban work, or part of it, was paid in specie. This also occurred with payment to servants and maids in the seigniorial houses and ecclesiastical institutions. In 1566 the Count of Benavente dedicated more than $60 \%$ of his wheat income to the payment of servants and similar costs. Osuna, legs. 242, 483, exp. 2, AHN.
} 
these four factors combined that determined the rate of the evolution of prices in these disparate and distant regions.

The effects of this rise in prices on the Spanish economy will be considered later. Of immediate concern is the question of how the globalization promoted by the Iberian empires would encourage and transform trade between the regions of Europe.

Although its importance has been exaggerated, the world-wide increase in monetary circulation was clearly one of the reasons for the price revolution. Certainly money in itself did not create trade, nor was it the only thing that contributed to the improvement in methods of payment and facilitated transactions (this was still more true for 'good money' coined from silver or gold). Systems of compensation to account, letters of exchange, whose endorsement was extended, or the cheque, clearly more widely used during the century, helped to secure these outcomes. However, the abundance of good coin was undoubtedly a factor that cannot be overlooked in attempting to explain such a process; this is especially true if we consider that if many of these operations and methods of payment saved on the use of cash, in the end they also implied monetary transactions, even if these involved lower quantities.

In addition, and despite its limited use, the growing amount of good money led to the development of a form of international trade which, even though it was different from local commerce, was also closely related to it. Taking into account the interaction between the development of urban networks and the deepening of rural market circuits, the maintenance and development of these networks - encouraged by the more long-distance trade and, therefore, by the growing use of gold and silver coins-accelerated the economic changes that had been taking root among peasant families and had begun in the previous century. And this took place in spite of the fact that in many regions of Europe gold and silver were rarely used.

The abundance of precious metals and their steady flow into the coffers of the monarchies made it easier to achieve stability in the value of the European currencies against silver. In turn, this led to a greater degree of exchange rate stability among the different European currencies themselves. ${ }^{14}$ Only France underwent repeated currency depreciations. This stability is important not because of the insights it offers into the relations

\footnotetext{
${ }^{14}$ See the chart of Braudel and Spooner for evidence that the sixteenth century, and specifically the first half of it, was a period of relative stability in this regard when compared to the seventeenth century (Braudel and Spooner 1967).
} 
of currency exchanges. Rather, it is significant because it accustomed merchants to operate in a world where monetary manipulations, although in existence, were more exceptional, thus contributing to a certain sense of security which was a guarantee for the development of business.

If, as it has been said, the output of German mines had exerted a relativebut decisive-effect on the commercial growth of the last decades of the fifteenth century and the first of the following century, then so when, from 1530, the American mines began to take over, they would become a factornot the unique one but certainly an important one-in bestowing upon an increasingly commercialized economy the means of payment that constituted the essential lubricant of this development.

\section{Markets and Trade Networks}

Due in part to eighteenth- and nineteenth-century theories, the possession of colonial empires has often been considered an important factor in economic growth and industrialization. According to these ideas, empires have played a crucial role in obtaining colonial raw goods and developing overseas markets for European industries. Fundamentally, Wallerstein (1979) continues this basic approach, although his vision is a much more refined one, and he and others have used dependency theory to interpret the sixteenth and seventeenth centuries. The Spanish and the Portuguese empires, in this long-standing paradigm, were missed opportunities already in the sixteenth century; dependency theory has strengthened even further this vision of the history of Iberia and Europe in general. The Castilian and Portuguese imperial ventures have, therefore, been seen as anomalies in the history of modern empires (Yun 2010).

The basis of this idea has been, however, highly criticized by some historians. Years ago, P. O'Brien (1980) drew attention to the extremely small size of colonial markets and the difficulty of attributing a decisive role to them before 1750. Whether or not this was a useful model for the British or European economy of the 1700s, its application to the situation of Castile and, indeed, to the old continent in general in the 1500s is very convincing. Indeed, for some time I have been arguing that something similar to this model is a good fit for the Spanish empire (Yun 1998, 2004, 2010).

Furthermore, in contrast to the common opinion among historians, the chances of the emergence of high demand for Castilian (or European) goods in America or in Asia were not that great. In order for a powerful colonial market for European products to emerge, it was first necessary for 
the local society to pass through a complex process of acculturalization, which matched local demand to the European patterns of consumption and industrial production. Moreover this change could only be achieved in the long term and by non-commercial mechanisms that were more closely connected to violence, war, and the creation of intra-colonial circuits of trade (Yun 2013). The demographic crisis brought about in America by contact and conquest further reduced the potential capacity of this market. Around 1580, when smuggling was only just beginning in earnest, annual shipments to the Indies were not greater than the internal trade of a city such as Córdoba. Quite possibly, the amount of textiles being exported to the overseas dominions did not reach the quantity sold on the market of this city (Yun 1998). Although often forgotten by economic historians, this is entirely logical: around 1580 only 250,000 white settlers lived in Spanish America, meaning that the potential demand for the products from the Old World was rather small. This signified the equivalent to between $4 \%$ and $5 \%$ of the existing theoretical additional demand of the Iberian Peninsula. At this juncture, a number of local industries in sectors such as textiles were also emerging, while construction (one of the most important) and other branches were largely tied to essentially regional circuits and had a very small impact upon the industrial sector of the metropolis. The rise of the American empire was not, therefore, an extraordinary missed panacea for Iberian industrial development, simply because the opportunity was rather small until around 1580 at the earliest.

And this context must inform our understanding of the evolution of the European economy in general and of the Spanish economy in particular during the sixteenth century.

In short, the first phase of this primitive globalization does not seem to have been based on the creation of very dynamic overseas markets for European (or Castilian) industrial products. Moreover, Europeans soon were able to use American silver to level their balance of trade with Asiathe true centre of the world economy, contrary to the preaching of an overly mechanical application of dependence theory-thus making it unnecessary to increase their exports to Far Eastern markets, and, therefore, the need to develop an industry able to balance or compensate its trade with the East.

But it is also obvious that, from a commercial point of view, there can be no doubt that this process saw an increase in the movement of goods at the global level and, in particular, a rise in those heading to Europe. Even scholars such as O'Rourke and Williamson (2002), who have 


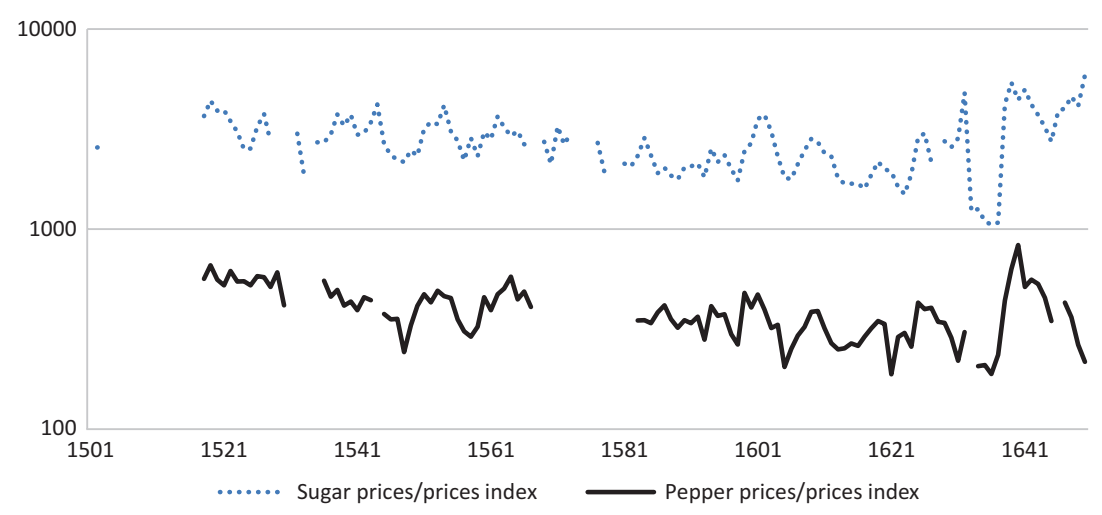

Graph 2.1 Sugar and pepper prices in regard the prices index in Castile Sources: My own elaboration based on data from Hamilton (1975, Appendix III, IV and V) and Reher and Ballesteros (1993). Prices of sugar and pepper from Old Castile.

relativized the impact of this period's international trade in the process of globalization, have shown that the increasing flow of pepper into Europe was crucial for the fall in the real prices of this commodity, a trend that demonstrates the relevance of this commerce. Other products reveal the same pattern. In Graph 2.1 the evolution of sugar and pepper prices in relation to the price index in Andalusia shows a similar trend. It is also evident that globalization produced an exponential increase in the slave trade, and the same happened with products such as cacao, cochineal and other dyes, and many other goods.

This process also facilitated a growth in intra-European trade. A high proportion of the Portuguese cargoes that arrived in Lisbon from Asia and Africa to be re-exported to Northern Europe were compensated by an inverse trade of tin, copper, lead, mercury, wood, alum, and other goods towards Portugal. The arrival of American silver into Europe, via Spain, had similar effects. It not only enhanced previous trade from Northern Europe to the Iberian Peninsula but was also a positive factor in allowing for more Iberian, and in general Mediterranean, commodities, such as salt, wool, and others, to be exported to the north.

To what extent, then, did this commerce break with the poly-nuclear model of development that previously existed in Europe (Chap. 1)? The answer to this question allows us to provide a more in-depth analysis of the concrete effects on international commerce. 
Spanish silver and the products of the Castilian and Portuguese Atlantic economy that arrived in the Low Countries and England also encouraged the connections with the faraway areas of the Baltic Sea. ${ }^{15}$ Thus, Northern Europe, and, in particular, Antwerp, was greatly favoured by the commercial development of the Atlantic front and the Iberian trade with America, Africa and Asia (Van der Wee 1963, vol. II, Chap. 6). The beginning of the rise of the city was related to the arrival, from the start of the century, of Portuguese cargoes. Until the 1530s Lisbon merchants, many of them of converso origin, faced the problem of not having sufficient quantities of African gold to meet payments for spices and so sought in Antwerp the silver and copper that the Fugger and the Welser obtained through the lease of the royal mines of Tyrol. This also contributed to enhance the trade between Iberia and the north of Europe.

The first impact of this new connection was quick to make itself felt on the functioning of European commercial circuits. If until this juncture products from Asia were unloaded at Venice and then redistributed across Europe, now they would descend from the Low Countries, through the fairs in Lyon, while silver and copper from Central Europe was sent up to Antwerp in increasing quantities (Gascon 1972). This transformation was accompanied by a greater dynamism of overland continental trade, evident in the increase in the movement of cattle from Denmark, North Germany, Hungary, and Central Europe towards the Netherlands (for the European routes, Map 2.1).

The aftermath of the difficulties of the 1520s saw the decisive moment for Antwerp, a city which, despite the persistence of certain problems symptomatic of fluctuations in American trade, would now experience an unprecedented phase of expansion (Van der Wee 1963). It then forged increasingly close connections with England and developed its own luxury goods and linen industry, thanks largely to the Low Countries' growing links with Iberia, one of the main markets for its manufactures, which it exchanged for wool and other raw materials. ${ }^{16}$ Mid-century Antwerp was,

\footnotetext{
${ }^{15}$ To give just one example, trade in rye rose from 20,900 tonnes in 1490 to 46,200 tonnes in 1557 (Zytkowicz 1985, p. 66). We might also consider the growing quantities of furs, wood, wax, salted-fish-Iberian salt was already common in the Dutch provinces - and many other heavy but widely dispersed items whose consumption was growing.

${ }^{16}$ Pach (1968). Van der Wee (1988) underlines the importance of the Castilian market for Flemish production (tapestries, high-quality fabrics, all types of artistic objects, etc.).
} 
therefore, a commercial and industrial centre of the first rank. It was the meeting point for select and expensive products from the south and the heavy and popular products of the north. And it also served as a point of redistribution throughout Northern and Central Europe for Iberian silver; sugar, spices, and many other Atlantic, African, and Asian goods; and a sizeable part of Italian production. In addition, the city's economy was based on a powerful and diversified industry that was increasingly tied to the production of high-quality and artistic goods. Antwerp oversaw the emergence of certain trading techniques and financial developments (Van der Wee 1988, pp. 184 and ff.). From the beginning of the century, German houses (the Welser and the Fugger) had displayed through Antwerp their interest in financing businesses in the Portuguese and Castilian colonies and in advancing monies to Charles $\mathrm{V}$; now the city saw the emergence of methods conducive to the streamlining of credit (Ehrenberg 1955).

Political factors were important to all of these changes. The formation of the dispersed composite monarchy of Charles $\mathrm{V}$ did not presage the disappearance of the numerous existing trade barriers among his territories. All were governed by different constitutions and a diverse array of commercial and political elites, and each one of them would retain its jurisdictional specificities. A genuine process of economic integration as it is understood today was all but inconceivable. The fiscal and monetary diversity of these territories and the existence of corporations of local merchants staunchly determined to maintain their privileges created barriers to outside penetration of many sectors and regions. However, the formation of this complex and dispersed political network in Western Europe also would have some positive effects for the internationalization of commercial networks and the integration of regional economies within this territorial mosaic. The consciousness of having a shared king gave an elite of businessmen close to the Court a certain security in regard to the stability of commercial links. That Charles implemented a policy of monetary stability in some of his domains no doubt helped deepen relationships between them. The case of Flanders and Castile and the relations of exchange in relation to silver is a good example. Although caution should be exercised in approaching this theme, Graph 7.2. demonstrates how, if the seventeenth century was characterized by both currencies being prone to considerable fluctuation, the sixteenth century, above all until 1569, would be marked by a high degree of stability and, therefore, predictability. 
Political factors would also have a definite impact upon international trade for financial reasons. Despite the so-called Castilian monopoly on American trade, the Fugger penetrated into the colonial economy by contracting asientos with the king in exchange for the import of goods which were traded in Europe (Kellenbenz 2000). And the same can be said of the penetration of the Welser into the slave trade that was present across extensive areas of Europe (Kellenbenz 2000, p. 225). The growing ease with which Spanish wool was travelling to Flanders, and with it the ever more fluid trade of Flemish and German goods into Castile, was related to the loans that these bankers, together with the Genoese, provided to the Emperor and which, given the ban on exporting currency from this kingdom, led to the repatriation of their loans and the interests accrued on them by sending commodities to other areas of Europe (Ruiz Martín 1990a). The growing trade in silk between Granada and Italy originated in the lease that Charles, always needing money, conceded to the Genoese for this commerce.

But did the emergence of the Atlantic and this growing trade represent a setback for the Mediterranean economy? Did it lead to a more polarized economy with a dynamic North and a retarded South? It would appear that it did not. Certainly, there were some areas in the South that drew benefits from this process. Among them is the obvious case of Genoa. Favoured by the vacuum left by the expulsion of the Jews, and having gained access to monarchy's finances, the great bankers consolidated Genoa's fortune. If German bankers were able to capture part of the production of raw materials in Iberia, Genovese connections were not weaker-on the contrary (Carande 1987, vol. I, pp. 295-315). Their hand would be greatly strengthened after 1528, when Genoa in effect became a protectorate of Charles $\mathrm{V}$, who, in turn, would create the fairs in Besançon as a means of counterbalancing the weight of the fairs of Lyon, while the Tuscans became the allies of the King of France. These developments would extend the influence of the Genoese into the North and the Netherlands, which would be decisive for the splendour of Genoese banking during the reign of Philip II and the establishment of a commercial and financial network unprecedented in Europe (De Maddalena and Kellenbenz 1986). As early as the 1540s, the Genoese were already the largest foreign colony in Flanders after the Castilians. Venice also resisted the pull of the North. From the 1520s it reacted with noticeable results in the spice trade, and the importance of the Venetians in Lyon's spice trade recovered up to $85 \%$ by $1533-1534$ (Gascon 1972 , p. 646), thanks to 
new routes through Asia Minor and Aleppo. In the lagoon city, many resources were ploughed into industry, a sector that would diversify in response to the demand for quality that would, in turn, encourage further industrial diversification and boost new and very dynamic sectors such as printing, glassware, and others (Sella 1957; Lane 1973, pp. 308-12). If the Genoese were able to cope with financial competition from German banking in the Court of the Habsburgs and even, through it, to control sectors strategic for trade, Tuscan banking would further strengthen its position in the market of Lyon, where it established strong bonds of financial and political complicity with the King of France (Gascon 1972). Such developments took place while the Florentine industry maintained a remarkable rate of growth that would reach its climax in the 1560 s (Malanima 1982).

Despite the importance of colonial trade and the development of the Atlantic front with its links to the global economies of America, Africa and Asia, the European economy did not fit the model applied to it in a mechanical application of the theory of dependence. Far from leading a hierarchical relationship of subordination with regard to a central axis, the growth of the first decades of the century remained a process based upon various centres (see Chap. 1). One needs to think also that, despite the striking development of the Atlantic façade, the penetration of international trade into family economies and regional markets was still too small to determine the models of economic growth of large geographic areas. ${ }^{17}$ This consideration, of course, does not preclude recognition of the crucial role of Atlantic trade in the working of the commercial networks within Europe.

These arguments lead to a consideration crucial for our case: the notable capacity that, from a relatively low level of use of resources, could be achieved by institutions that were apparently inefficient in generating growth according to the model of the new institutional economics. As a matter of fact, this international commerce, like the incipient trade with America, Africa and Asia was based on economic privileges and on the monopolistic access to resources and information.

\footnotetext{
${ }^{17}$ A comparison is instructive: the annual remittances of American silver that were paid to private individuals in Castile for commercial sales, services, and inheritance came to 2250 million maravedís in 1590-1591, when the gross domestic product of Castile was worth 30,000 million (Yun 1998, p. 131, n. 25).
} 


\section{Iberia In THE Global ECONOMY: LOWERING Transaction Costs}

\section{An Export Economy?}

The increasing role of the Iberian Peninsula in the expansion of foreign trade was clearly expressed by indicators such as the almojarifazgo of Seville or the periatge of Barcelona (Yun 2004, pp. 147-51). As was the case for Europe as a whole, incipient globalization may have induced a series of changes of great importance in patterns of consumption. The ever-easier access to foreign products, the expanding availability of methods of payment, and the increase of income derived from domestic economic growth would activate the demand for products of all kinds in the Iberian kingdoms. The rise of prices in the Iberian Peninsula must also have attracted foreign manufactured products. The fact that this economic growth was accompanied by the development of access to easy credit for privileged groups (see Chap. 4) would give further impetus to a form of ostentatious consumption that was already prominent in the societal mores of the time and which was satiated primarily with exotic, rare, or expensive goods usually sourced from abroad. The growing devotion of Iberian aristocracies and elites to the culture of the Italian and Flemish Renaissance would pull in the same direction (Brotton 2002). Partly as a result, a pattern of conspicuous consumption and ostentation took hold among the nobility and urban patriciate that was clearly linked to the cultural shifts experienced by these groups. As early as the reign of Charles V, many foreign travellers in Iberia referred not only to the spices consumed there but also to the rich clothes and the damask and taffeta that adorned the persons and homes of the nobles and great businessmen or to the ornamental richness of the churches and palaces. ${ }^{18}$ Demand of this sort was met by the consumption of expensive fabrics and objets d'art imported from Italy and Flanders, whose industries quickly benefited from this demand, ${ }^{19}$ as did

\footnotetext{
${ }^{18}$ N. Popielovo Viaje de Nicolás de Popielovo, in García Mercadal (1999, vol. I, p. 300), J. Munzer, Viaje de Jerónimo Munzer. Ibidem, p. 309, 310, 374-5. Guicciardini Relación de España, Ibidem, p. 585.

${ }^{19}$ Van der Wee (1988). Dámaso de Frías, a traveller of the epoch, refers to the 'alteration of the costumes, customs and manners of living that we see in all of Spain since the Flemmish entered into it', specifying the abandonment of 'temperance' and the 'old parsimony in eating habits of the Spaniards', Diálogo de Alabanza de Valladolid García Mercadal Ibidem. p. 247.
} 
their counterparts in France (Rouen and Nantes above all). And it would seem that this process was increasingly influential as the reign wore on as new lifestyles, linked in part to the palace and the adoption of more refined habits, took root (Checa 1988, pp. 195-216).

This trend would even further encourage the reverse flow of exported raw materials from the peninsula to the rest of Europe. Wool shipments, undoubtedly the most important of all of the Spanish export products, increased threefold in volume during the first half of the century. The same thing occurred in Aragon where, in addition to wool, leathers and saffron were also prominent in exports (Gómez Zorraquino 1987, pp. 87-98). Sugar and silk were exported from Valencia in growing quantities, as was silk from Granada and Murcia and the alum of this latter region. ${ }^{20}$ From the middle of the century (the start of the second cycle of the Atlantic economy), the role of Castile and Portugal as bridges in the trade of raw materials coming from the New World was accentuated as large quantities of cocoa, hides, sugar, cochineal, and other products arrived, part of which was exported to other areas of Europe (Phillips 1990, pp. 58, 80, 70).

Several factors contributed to these changes. In Castile, the improvement of the fairs system pivoting around Medina del Campo, Medina de Rioseco, and Villalón was, without doubt, one of them. These were institutions whose commercial regulation would help reduce an initially very high level of transaction costs and risks. For some time these fairs had constituted an important meeting point for foreign merchants and Castilians. During the sixteenth century, the co-ordination of payments between the Castilian fairs and those of Antwerp and Bergen op Zoom was established on near-perfect footing, as was the internal trade fair circuit within Spain (Carande 1987, vol. I, p. 331). Links of this kind further reduced information costs and uncertainty and guaranteed spatial and temporal convergence of supply and demand, thus allowing the establishment of a regular system (and therefore one of more predictable operations involving fewer risks) for transferring funds between them. The increasing importance of fairs allowed the monarchy to channel payments through them, thus permitting it to borrow from and make repayments to asentistas and bankers present at these gatherings. In turn this practice provided a stimulus to large-scale businessmen who, needing money to

\footnotetext{
${ }^{20}$ Furió (1995, pp. 244-5), Pérez and Lemeunier (1984, pp. 77-9). Cortés and Vincent (1986), Ruiz Martín (2005).
} 
meet their commitments to the king, channelled growing quantities of products and bills of exchange through these meetings. (Abed Al-Hussein 1982). During the middle years of the century, the annual amount paid by the king in this way could even touch 2,000,000 ducats, a figure of significance if we consider the gross annual income of the monarchy in Castile might reach five or six million at this point (Yun 2004). ${ }^{21}$ The impulse behind the fairs was also linked to the development of the American economy that forged sudden, and intense, ties. Around 1520, of 186 letters negotiated with fairs from Seville, 107 referred to trade with Lyon and only 79 with the other fairs of Castile (Otte 1986). But this ratio, if itself of some importance in a year of civil war and intense conflicts in Medina del Campo, would rise during the following decades. The fairs became a circuit linking the whole global economy, from Southeast Asia to the Caribbean, Lisbon, Seville, and Antwerp, and reaching as far as the more developed areas of Italy. Its importance with regard to the development of foreign trade is therefore undeniable.

A similar result emerged from the foundation and development, begun in the fifteenth century, of consulates in Castile that were similar to the existing ones in the Crown of Aragon. The Consulate of Burgos was established in 1494. Bilbao followed suit in 1511. Seville, where by 1503 the Casa de la Contratación already existed, would have to wait for the Real Provision of 1543 and the ordenanzas of 1556.22 The effects of this type of institution would be immediate. Despite friction between them (especially between those of Bilbao and Burgos) and the not-so-positive future evolution (see Chap. 5), the consulates would initially improve the organization of the convoys and maritime insurance system. Above all, they enabled special courts and arbitration systems to reduce transaction costs by making judicial review a more agile, rapid process (as is specifically clear from the ordenanzas of Burgos and Seville) and so increased guarantees of responsibility and agreement among their members. ${ }^{23}$ Membership in a consulate created bonds of trust and even, in some cases, of shared responsibility among merchants, traits which were especially valuable in

${ }^{21}$ Dirección General del Tesoro, Inv $^{\circ} 24$, legs. 490, 1299, 1458, 815, 1432, 491, 492, 494, $495,561,561$ bis, $562,563,564,565,566,567,568,569,570,571,572,573,574,575$, AGS.

${ }^{22}$ Basas (1994, pp. 25-40) and García-Baquero (1992, pp. 57-84).

${ }^{23}$ Basas (1994, pp. 33-6) and García-Baquero (1992, pp. 74-9). 
the operation of trading diasporas. While networks such as that of Burgos (active across Europe and particularly in the north of the continent) had been created much earlier, there are good reasons for thinking that these organizational improvements substantially increased their projection into the Netherlands during the first half of the sixteenth century.

The development of powerful financial networks across the peninsula would also contribute to the expansion of international trade. Here it is worth repeating that the export of wool, silk, and colonial products was activated by the advancing of money in the form of the renting out of royal incomes and taxes by merchants and bankers. The same happened with alum, a mordant necessary for the production of fabrics, which was purchased by the Genoese from the marquis of Vélez and the duke of Escalona through similar mechanisms (Ruiz Martín 2005). Sugar was purchased from the duke of Gandia in Valencia, as was the saffron, wool, and other products that formed part of the seigniorial rights of Aragonese nobles, who rented them out to financiers in return for the loans necessary to overcome their liquidity problems. ${ }^{24}$ Even without these institutional advantages, these networks were able to absorb a large part of production. Thus, the merchants of Burgos acquired wool through a system of advancing credit to the shepherds when they were most in need of money-that was before the wool itself had even been shorn from their sheep. The Genoese not only used mechanisms of credit based upon the king's revenues or those of the aristocratic houses. Their loans to the banks and merchants of Seville involved in the Carrera de Indias also served to give them indirect access to goods from America. ${ }^{25}$ On the east coast, the Genoese not only secured the purchase of Granada silk through financial mechanisms. They also purchased wine, raisins, barilla, sugar, and other products sold to them by growers in need of cash; their actions were clearly favoured by lower costs achieved through well-established, well-oiled networks and their control of these trade circuits (Pérez and Lemeunier 1984).

These ties (accords between businessmen and the monarchy or with individuals through the leasing out of rents or simple credits) also explain the erection of entry barriers and the consolidation of oligopolistic mechanisms that reduced the capacity for the distribution of wealth of this trade. This would become notorious later on. But, again, for the moment and

\footnotetext{
${ }^{24}$ Carande (1987, vol. III), Halperin (1980, p. 27), and Gómez Zorraquino (1987).

${ }^{25}$ Edwards (1977) and Fortea (1981, pp. 341-5).
} 
under certain conditions, such connections could lower transaction costs and risk in the context of institutions that the new institutional economics considers inefficient.

\section{A Semi-periphery of Europe? Domestic Trade and Institutional Improvements}

The development of foreign trade and the export of raw materials created significant tensions within the peninsular economies. Many sectors of it, such as high-quality textile production, found themselves having to compete with powerful importers of goods of a similar-or, indeed, higher-quality and with exporters of raw materials essential for the elaboration of their own merchandise. Likewise, the barriers to entrance created by the groups of contractors and financiers who secured a large share of raw materials through financial mechanisms further reinforced this situation and were conducive to the financial subordination of Iberian banking by the great cosmopolitan international financial houses (Ruiz Martín 1990b). But does this situation justify reference to a 'semi-periphery'?

There are reasons to think that it does not. Castilian bankers were mainly focused on the internal market. But it is also true that, thanks to their international links and the commercial expansion, some of them were able to operate in cross-border spaces and to use more modern techniques to that end. They developed considerably during the first half of the century, as is demonstrated by the rise to prominence of families such as the Ruiz, the Maluenda, the Bernuy, the Salamanca, or the Calatayud and many others (Carande 1987, vol. III). Some, like the financiers of Seville, did so in collaboration with the Genoese. Others, like the young Simón Ruiz who, according to his brother, Andrew, 'would not confine himself to having all the treasure of the world', acted independently in the international arena (Lapeyre 1955, p. 74, n. 176). All of them mastered the art of the letter of exchange and the account books (Lapeyre 1955). And a similar development occurred in Portugal. Certainly, the role of international bankers in providing loans to the king in the Low Countries was crucial and was going to condition the development of the Portuguese banking system. But, at the same time, these decades witnessed the development of international commercial and financial networks through the agency of the Portuguese Jewish merchants, which would be very relevant after 1580 (Boyajian 1983). 
Though we will come back to the manufactures' development below, it is important to note here that there were also industrial sectors within Iberia that would take advantage of international ties. Córdoba leathers and other embossed leather goods were exported by the Genoese themselves and even arrived in significant quantities in Flanders, where they would be much imitated (Van der Wee 1963). The textile industries of Córdoba and Segovia were able to begin to adapt to demand for higherquality merchandise thanks to the replacement of cruder dyes (sourced within Spain) by pastel (an import) and thanks to the alum extracted by the Genoese capital in Murcia (Fortea 1981). Cochineal, brought from America, would bring noticeable improvements to fabrics and light cloths (Marichal 2014). The Basque iron industry faced intractable problems due to competition from other areas after 1550 , but its expansion to reach 'optimal production' seems undeniable up until that date-an expansion for which domestic demand was partially responsible but which, in view of exports to England, should also be seen as the effect of external demand favoured by the increasingly close relationship between the economies of the peninsula and Europe (Bilbao 1987, pp. 49-57). One manifestation of the expansive capacity of domestic industry can be found in the petition made to Charles $\mathrm{V}$ in the Cortes asking him to raise the quota of wool that had to remain in Castile in 1552. This was precisely the moment at which, in Córdoba, the growth of the textile industry meant that 'the tensions in the wool market took on a whole new dimension' (Fortea 1981, p. 350).

The expansion of ties with the international and colonial economies was, together with the military needs of the Crown, the fundamental cause of the development of both the military and merchant navy, which had been growing since the fifteenth century and which enhanced the naval industry and the demand for wood, iron, copper hemp and other industrial products. This fact, though poorly known, is no longer in doubt. The idea of a limited and insufficiently developed Spanish navy can no longer be sustained, although it has been reiterated in a great deal of the international literature (Casado Soto 1998). It was always supported by the Crown, which above all else was interested in the construction of successively larger vessels (Carande 1987, vol. I, pp. 351-414). In the Crown of Aragon, Barcelona became the most important construction centre for galleys in the peninsula (Goodman 1988, p. 96). By the mid-century it was already facing a crisis of 'accelerating demand' for maritime transport vehicles (Casado Soto 1998, p. 353). This explains the expansion of this industrial sector in cities such as Seville, Bilbao, and the aforementioned 
Barcelona. The Iberian countries became central points for the development of naval technology. This was even clearer in Portugal, where the size of the navy increased dramatically between 1500 and 1560 (Costa 1997 , p. 265). In the Portuguese capital, this sector also activated demand for industrial products, above all in the cities of the lower Tagus and the zones between Porto and the Galicia frontier. For these reasons it has been even possible to speak of a 'state capitalism', due to the direct involvement of the Crown in these businesses, which were crucial for its trade monopoly (Costa 1997, p. 262).

While encouraging the export of raw materials and the import of industrial products, the Castilian fairs also had positive effects on the domestic economy which gained in consistency and internal coherence. The trading system based upon synchronized periods between meetings held in the different places served, moreover, to reduce transaction costs and transport risks also for products moving within the internal market too. Many merchants from different regions of the peninsula, including Portugal, approached these gatherings with the guarantee that they could securely buy and sell their products in an environment of intense commercial activity and relatively abundant liquidity and with the confidence that they could defer part of their payments if necessary (Yun 1987, pp. 186-95).

The fairs were a stimulus for the development of agriculture and animal husbandry. The benefits were felt from the vineyards of Medina del Campo to the wheat fields of the Tierra de Campos and across the northern plateau where livestock herds grazed (Yun 1987). And they also sparked many other commercial sectors. The effect of these developments was to boost interregional trade between the plateau of Castile and the snow-topped mountains of Cantabria. Areas such as La Rioja awoke to their industrial vocation thanks to the effects of these periodic reunions. ${ }^{26}$ And they had the same effect as had on the textiles of Segovia and even, further afield, those of Cuenca. Fair meetings carried forward the creation of the internal market, as is demonstrated by the presence at them of merchants from as

${ }^{26}$ Although little studied, this theme is mentioned in numerous references found in the Archivo Histórico Municipal de Medina de Rioseco, hereafter AHMMR. See, for example, leg.13 (ant.) exp.298 (especially, the Memorial del pleito de Medina del Rioseco contra el Conde de Benavente). 
far afield as Córdoba, Seville, and Granada and the regular circulation of bills of exchange originating in these cities (Fortea 1981, pp. 395, 398). During this period, the financial market of Medina del Campo continued to serve the industry of Granada by advancing capital to it (Abed Al-Hussein 1982). The contribution of the fairs system to the formation of the Iberian trading network can also be shown in regard to Portugal, whose traders sold sugar, spices, and other overseas products into it; they also purchased cloth, not all of which was manufactured abroad, with considerable quantities produced in Segovia or Cuenca. Some time ago, P. Vilar provided an account of the intensification of traffic between Barcelona and Medina del Campo, explaining how the latter served as a staging post for the fabrics and leathers which the Catalans exported to America and how soap carried to Portugal through Castile was exchanged for 'brazil', a dye that undoubtedly helped to boost the textile industry (Vilar 1962, vol I, pp. 333-4).

The increasing interconnection of the domestic market was also the result of many other currents and flows that bound different circuits together. Relations between Andalusia and Portugal, and Lisbon in particular, appear to have been established before the annexation of 1580 , as is demonstrated by not only the increasingly important role of the Portuguese in Seville but also their presence in Córdoba. Toledo acquired its 'role of regional redistribution centre', where the markets sold textile products from the northern and southern plateaux and even from Valencia and the kingdom of Aragon; and this came at a time when its relations with Andalusia and Portugal also intensified through the supply of Atlantic and Asian products in exchange for products coming from different mainland areas (Montemayor 1996, pp. 238, 255-61). Trade between Castile and Aragon was also reinforced. Isolated data provided by Lapeyre on Castilian customs has revealed that Catalan fabrics and Perpignan cloth were both imported and, moreover, that an intense trade was maintained with Valencia, where Castilian wheat was sold in exchange for goods including silks, citrus fruits, and rice (Lapeyre 1981, pp. 47-9). These expansive trends in internal trade are clearly visible in some commercial indicators of a more quantitative character (Yun 1987; Montemayor 1996).

Political and institutional reasons also pulled in this same direction and contributed to the reduction of risks and costs of transaction in longdistance commercial operations within the Peninsula. In regard to the currency, the Emperor's reluctance to undertake devaluations is well known. 
He was loathed to introduce measures that, indirectly, would have meant a certain convergence of the monetary systems of the various kingdoms during the first third of the century. ${ }^{27}$ There were sound financial reasons for this policy. However, Charles V's reluctance disappeared in 1537 with the order to issue escudos of 22 carats equivalent to 350 maravedís, which seems to have positive effects. ${ }^{28}$ In a similar vein, the reduction of the vellón to 5.5 grains in 1552 facilitated lower-level trade and the circulation of fractional currency, vital for local and regional trades and the development of commercial and artisanal activities, in which this type of coin was commonly used (Hamilton 1975, pp. 69-70). The beneficial effects of these operations are better understood in light of the reflections of Sargent and Velde on 'small change' (2002).

Another important advance was found in the policy of appointments and the creation of notaries. This phenomenon, always interpreted from the perspective of power relations and whose limits we will study, has a certain relevance as means of guaranteeing contracts in a society that until this point had based its guarantee on personal knowledge or the endorsement of intermediaries known by both the seller and buyer. In these years the role of the notary or scribe came to be defined in great detail, although this policy actually stretched back into the fifteenth century. ${ }^{29}$ In 1503 the Crown sought control of the appointment system, with the aim of ensuring the competence of the office holder, ${ }^{30}$ while Charles $\mathrm{V}$ was concerned because the appointments of these officials were approved by the justice of

${ }^{27}$ See Hamilton (1975, pp. 67-8). The requests of the Cortes for the reduction of the quantities of silver and gold in the different coins (the ducat or ducado y la blanca, above all) can be found in Actas de las Cortes de Castilla (hereafter ACC), M. Danvila (ed.) (1861), vol. IV, p. 328 y 388-93, among others.

${ }^{28}$ This measure brought the currency into line with the monies then circulating in France and Italy, thus limiting its outward flow towards these countries and improving its interior circulation in more important transactions. At the same time, it also served as an incentive to trade between Castile and Aragon, as there was now a standard measure with the money that had been circulating in Catalonia since 1535 (Hamilton 1975, p. 69).

${ }^{29}$ In order to prevent the appointment being made by arbitrary methods that might result in the naming of unqualified individuals, in 1480 the Catholic Kings decreed that 'no title of scribe of the chamber, nor of public scribe, should be given to anyone other than a qualified person, one examined in the council and with licence from the king'. At the same time, their duties and requirements were defined (Nueva Recopilación, libro IV, Tit. XV, ley I).

${ }^{30}$ This was done at the same time as appointments made by other means were revoked. Nueva Recopilación, libro IV, Tit. XV, ley V. 
the town or city in question. ${ }^{31}$ Yet, piecemeal legislation was handed down that regulated the formal conduct of these officials, with the aim of improving their status as bondsmen for contracts, something which was in principle positive for trade and transactions in general. ${ }^{32}$

Although the regulation of notaries and scribes produced no decisive qualitative change, this sort of measure may well have had some positive effects, especially if we consider the relatively insecure initial situation. ${ }^{33}$ This policy would strengthen with the improvement of the Chancillerias, whose support for the fulfilment of contracts and judicial functions is well known (Kagan 1991). It resulted in legislation that provided guarantees on commercial transactions, contracts, and compliance, ${ }^{34}$ with

${ }^{31}$ In this regard, see law III (of 1534), or law XVIII, in which an order is given with the aim of extending the scope of action of the scribes, with the corresponding effect of enlarging their role as guarantors and so reducing uncertainty in transactions. Specifically it states that 'we order the corregidores and justices of cities and towns of these our kingdoms that they should compel and reward the scribes of a number of them that go out into the land to take writs and despositations as they are asked [to do]'. Nueva Recopilación, Libro IV, Tit. XXV, ley XVIII.

${ }^{32} \mathrm{An}$ attempt was made to avoid nepotism in the actions of the scribes, who often fell into this trap when dealing with the networks of monasteries and religious institutions. New norms were set down, with annual checks, new protocols, and norms of behaviour stipulated for testimonies, and writs, with the aim being to guarantee the efficacy of the system. See Nueva Recopilación, Libro IV, Tit. XXV, passim.

${ }^{33}$ The importance of the measures introduced in regard to scribes should be underlined. They were not brought about by a new drive by the Crown to set down rules and control social life, although at times the towns criticized these measures on these grounds. On the contrary, on more than one occasion, the Crown asked for the extension and strengthening of the powers of these officials, without doubt because of their quest to inculcate greater respect among private individuals, a quality that was increasingly important for the urban oligarchies as a means of reducing risks and increasing security in economic relationships of an ever more impersonal and market-orientated nature. Thus the City of Granada included among its petitions of 1542 that the clause should be respected that anyone using his property for a censo should register it before a scribe of the council and that no alternative arrangement should be allowed. It is very necessary, it went on to note, for the good of these kingdoms that those who engage in contracts should not be misled. Patronato Real, 69-82, AGS.

${ }^{34}$ Aside from the Nueva Recopilación, other collections of legislation of this period can be found. See the wealth of norms and rules on companies that are found in Hugo de Celso, Repertorio de las Leyes de Castilla, Madrid, 2000 (edited by Alvarado Planas), specifically, f. LXXV ff. 
provisions that aimed to standardize weights and measurements ${ }^{35}$ and the publication of compendia of laws. ${ }^{36}$ Although these measures were apparently aimed specifically at lawyers and men of justice, in all cases they sought to improve the legal system with the aim of building confidence in commercial activities and achieving a quicker settlement of disputes - a trait which, as is well known, is one of the keys to the development of trade.

All of these measures, in themselves conducive to the integration of markets, were accompanied by a fall in the costs of transport. The phenomenon is difficult to measure, and, indeed, no series of prices for transport costs can be given. But the signs are very clear. In the first place, prices were clearly rising, and, on the other, the supply of transportation was evidently expanding, trends which will be explained later (see Chap. 3). These circumstances must have led to a decline in relative prices of transport.

In conclusion, the formation of vibrant internal commercial networks could be interpreted as a negative phenomenon for endogenous development if it had served only to encourage the penetration and distribution of industrial products and the export of raw materials. But there certainly were industries which, although they had to suffer foreign competition, also drew benefits from the abundance of raw materials or the commercial advantages drawn from the expansion of the external sector. In addition there were sectors that were able to undertake a process of technical

\footnotetext{
${ }^{35}$ According to Hamilton (1975, pp. 168-9), the real advances in this regard were achieved during the reign of the Catholic Kings, while Charles, 'weighed down by the burden of the Empire and the cares of state, had hardly any time to devote to such prosaic tasks' (p. 169). We do not know the extent to which the reign of the Emperor saw an advance in this regard. As late as the 1570s, there were some who stated that in Salamanca a number of figures were 'somewhat lacking in their measurements and weights', 'pesas y medidas algo faltas', Cámara de Castilla, Libros de Cédulas, lib. 62, AGS.

${ }^{36}$ The collections of laws cited in this chapter should be seen in the same light. Their very survival implies a greater capacity to apply laws dealing with responsibility, commerce, risk, guarantees, and so on. As set down in the Nueva Recopilación of 1571, the new volumes use and cite pre-existing texts such as that of Diego Pérez de Salamanca, Repertorio de todas las Leyes y pragmáticas y Bulas..., Medina del Campo, 1549, or that of Hugo de Celso cited above (Repertorio de las leyes de Castilla... Op. cit.). In turn, this tome was first printed in Valladolid in 1538 and included new norms, rules, or guidelines on a wide number of matters such as 'debts and debtor' (deudas y deudor) f. XCII, 'contracts' f. LXXVII, 'guarantor and guarantee' (fiador y fiaduria) f. CXLV-CXLVII, 'buying and selling', f. LXXV, and so on.
} 
development and import substitution. As we will see in the next chapter, the expansion of urban networks and industrial development were both very consistent with such developments.

Spain and Portugal created a highly complex system in their colonies. Certainly it is problematic to describe it as an absolutist one (meaning one in which the king's authority was unchallenged and unrestrained), much as this has been the view of many scholars. Far from being a monolithic, wellcontrolled instrument whose logic can only be explained by the decisions taken in its hierarchical vertex, the Spanish and Portuguese colonial systems emerged as a complex binding of powers and working interests, simultaneously delicate and characterized by relatively decentralized decision-making processes. This is not to deny that major efforts at centralization and control were undertaken from the Lisbon and Madrid or that, as we shall see, these attempts became even more frequent from the end of the sixteenth century. The juridical code itself helped towards this, in part because it considered the colonies as belonging to the Crown (nor should it be forgotten that the king continued to hold rights over the land). The result was a high degree of autonomy, with a diverse number of decision-making centres but the existence of a central power that took responsibility for the government and regulation of social and commercial relations. In societies as complex as these, where the presence of the Crown and its degree of penetration into the social fabric varied, these arrangements would lead to levels and forms of negotiation that were very different from one another and which are difficult to set within the (usual) formulas of polycentrism and centralism.

Spanish and Portuguese institutions in both empires had in fact provided positive results for economic growth and expansion in the peninsula. But, being also appropriate to a society whose development had been based upon war and conquest, they also had a notable capacity for destruction. In other words, the rules of play were shaped by mechanisms leading to both the capture and destruction of wealth. At times, they were highly inefficient in replacing lost resources, largely due to the extremely limited development of medicine and the other tools necessary to resist death, which was the main challenge to emerge from the conquest. This fact was also seen in the way that the Spanish adapted existing American institutions to their use.

The impact of all of this in the colonies and therefore in the different patterns of empire had to be, however, very uneven. After 1492 a period 
of ecological imperialism took place in America, and the European institutional systems were to prove more adept at destroying the existing productive systems than at reconfiguring them rapidly with a more effective apparatus. Few episodes in the history of humanity have had such dramatic effects or such long-lasting ones. On the contrary, the effects in Africa and Asia were different. In the former, the slave trade, developing with Atlantic expansion, would lead to convulsions within the original societies. But the lower degree of penetration of the Europeans until the nineteenth century and their greater resistance to disease produced less profound social changes in Africa than in America (Headrick 2010). The population would even continue to grow throughout the sixteenth century. But in regard to Asia, the scope for the decomposition of the original societies and the establishment of destructive (European) institutions was also highly reduced. This was, moreover, a world with a microbial system close to that of the old continent and more resistant to diseases brought by the Europeans.

On the other side of globalization, Europe was affected as, especially, was Spain but not in the way we have supposed for years. The growth of trade to which America, the African coast, and Asia contributed did not break the model of poly-nuclear development of the fifteenth century, and the Iberian societies did not move to the semi-periphery of this New World economy. In this regard the institutional framework was crucial. The informal mechanisms for the creation of confidence and the reduction of risk appear to have been efficient, as can be seen in the trading networks based upon personal accords, familial ties, and reputation. The expansion of international trade is incomprehensible if we fail to understand this. And these institutions overlapped with the formal institutions created by the monarchy in both countries in a way that was beneficial for economic growth. This was not because of the intrinsic nature of these institutions but rather because of the huge number of resources available to them. The benefits were manifested in improvements to the system of justice, contracts, the use of money, international commercial organization, and interregional trade. Attention should also be placed upon the fact that even institutions based upon privilege, the use of the monopoly or expensive and asymmetrical information, appear to have had positive outcomes. To put this another way, they did not abort the capacity for growth prevalent in a society of abundant but unexploited resources. 
This leads us not only to relativize the impact of political or formal institutions on economic growth but also to think that their effects depend directly upon the context and the quantity of available resources. These conclusions will only gain strength in the following chapters, which examine the internal evolution of Iberian societies.

Open Access This chapter is licensed under the terms of the Creative Commons Attribution 4.0 International License (http://creativecommons.org/licenses/ by $/ 4.0 /)$, which permits use, sharing, adaptation, distribution and reproduction in any medium or format, as long as you give appropriate credit to the original author(s) and the source, provide a link to the Creative Commons licence and indicate if changes were made.

The images or other third party material in this chapter are included in the chapter's Creative Commons licence, unless indicated otherwise in a credit line to the material. If material is not included in the chapter's Creative Commons licence and your intended use is not permitted by statutory regulation or exceeds the permitted use, you will need to obtain permission directly from the copyright holder.

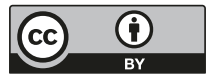

